OPEN ACCESS

Edited by:

Ahmed E. Kholif,

National Research Center, Egypt

Reviewed by:

Paulo Lima,

Universidade de São Paulo, Brazil

Anusorn Cherdthong,

Khon Kaen University, Thailand

${ }^{*}$ Correspondence:

Xuezhao Sun

xuezhaos@hotmail.com

Specialty section:

This article was submitted to Animal Nutrition and Metabolism

a section of the journal

Frontiers in Veterinary Science

Received: 28 July 2020 Accepted: 07 September 2020

Published: 09 October 2020

Citation:

Sun XZ (2020) Invited Review: Glucosinolates Might Result in Low Methane Emissions From Ruminants Fed Brassica Forages.

Front. Vet. Sci. 7:588051 doi: 10.3389/fvets.2020.588051

\section{Invited Review: Glucosinolates Might Result in Low Methane Emissions From Ruminants Fed Brassica Forages}

\author{
Xuezhao Sun ${ }^{1,2 *}$ \\ ${ }^{1}$ The Innovation Center of Ruminant Precision Nutrition and Smart and Ecological Farming, Jilin Agricultural Science and \\ Technology University, Jilin City, China, ${ }^{2}$ Jilin Inter-regional Cooperation Center for the Scientific and Technological Innovation \\ of Ruminant Precision Nutrition and Smart and Ecological Farming, Jilin City, China
}

Methane is formed from the microbial degradation of feeds in the digestive tract in ruminants. Methane emissions from ruminants not only result in a loss of feed energy but also contribute to global warming. Previous studies showed that brassica forages, such as forage rape, lead to less methane emitted per unit of dry matter intake than grass-based forages. Differences in rumen $\mathrm{pH}$ are proposed to partly explain these low emissions. Rumen microbial community differences are also observed, but the causes of these are unknown, although altered digesta flow has been proposed. This paper proposes a new mechanism underlying the lower methane emissions from sheep fed brassica forages. It is reported that feeding brassica forages to sheep can increase the concentration of free triiodothyronine $\left(\mathrm{FT}_{3}\right)$ in serum, while the intramuscular injection of $\mathrm{FT}_{3}$ into sheep can reduce the mean retention time of digesta in the rumen. The short retention time of digesta is associated with low methane production. Glucosinolates (GSLs) are chemical components widely present in plants of the genus Brassica. After ruminants consume brassica forages, GSLs are broken down in the rumen. We hypothesize that GSLs or their breakdown products are absorbed into the blood and then may stimulate the secretion of thyroid hormone $\mathrm{FT}_{3}$ in ruminants, and the altered thyroid hormone concentration may change rumen physiology. As a consequence, the mean retention time of digesta in the rumen would be altered, resulting in a decrease in methane emissions. This hypothesis on mitigation mechanism is based on the manipulation of animal physiological parameters, which, if proven, will then support the expansion of this research area.

Keywords: digesta retention time, free triiodothyronine, greenhouse gas, physiological parameters, plant secondary compounds, rumen

\section{INTRODUCTION}

Methane $\left(\mathrm{CH}_{4}\right)$ is an important greenhouse gas, with a global warming potential of 28 times more than carbon dioxide (1). Agriculture accounts for $62 \%$ of $\mathrm{CH}_{4}$ emissions from anthropogenic activities, while ruminants account for $58 \%$ of the $\mathrm{CH}_{4}$ emissions from agriculture (2). As a result, enteric $\mathrm{CH}_{4}$ emissions are the single largest source of anthropogenic $\mathrm{CH}_{4}$ contributing to the 
global greenhouse gas emissions (3). Methane emissions also cause energy losses in livestock, which account for $3.9-10.7 \%$ of the metabolic energy ingested, resulting in less efficient energy utilization by the animal (4). Reducing $\mathrm{CH}_{4}$ emissions, therefore, has the potential to improve feed conversion efficiency (5). Thus, mitigation of $\mathrm{CH}_{4}$ emissions helps not only environmental protection but also has substantial economic benefits to promote sustainable development of animal husbandry $(6,7)$. For this reason, mitigation of $\mathrm{CH}_{4}$ emissions from ruminants has become a highly active research topic in animal husbandry.

Methane is formed in the process of the rumen microbial degradation of feed in ruminants. The approaches to the mitigation of $\mathrm{CH}_{4}$ emissions include inhibiting methanogens with inhibitors (8) or a vaccine, modifying microbial activity in the rumen with electron acceptors, ionophores (9), or dietary manipulation (10), and breeding for low- $\mathrm{CH}_{4}$ livestock (11). Among these approaches, the use of brassica forages to mitigate $\mathrm{CH}_{4}$ emissions is a feasible method that does not change farming systems, increase production costs or result in artificial chemical residues.

The purpose of this review is to summarize literature reports on the use of brassica forage to mitigate $\mathrm{CH}_{4}$ emissions, analyze possible mitigation mechanisms, and highlight the possible role of glucosinolates, which are characteristic substances in brassica forages, in reducing $\mathrm{CH}_{4}$ emissions.

\section{RUMINANTS FED FORAGE BRASSICA EMIT LOW METHANE}

Brassica forage crops including kale (Brassica oleracea), turnip (Brassica campestris), forage rape (Brassica napus), and swede (Brassica napus ssp. rapifera) are annual plants, grown worldwide to provide ruminants feed, in many cases during the period when forage supply is limited in quantity or quality (12). These crops can grow in winter, but forage rape and bulb and leafy turnips can also grow in summer. These crops have high water-use efficiency and thus are suitable to grow in conditions of limited water resources (13). They have a short growth period (14), being easy to grow, with the ability to be intercropped with legumes (15).

Forage brassica crops have the characteristics of having a high yield, typically 2-8t dry matter (DM)/ha for leafy turnip, 3-10 $\mathrm{t} /$ ha for forage rape, 2-12 t/ha for turnips, 5-20 t/ha for kale and 5-20 t/ha for swedes (16). The leaves and stems of kale, leafy turnip, and forage rape are used for feed, while swede and bulb turnip are root brassicas with both leaves and bulbs being used. The chemical composition of brassica forages varies greatly among species and within a species mainly due to the difference in the ratio of leaves to bulbs or to stems (17). Compared with perennial ryegrass (Lolium perenne), brassica forages contain less neutral detergent fiber (NDF) and more readily fermentable carbohydrate $(12,18)$. The content of NDF is $271-328 \mathrm{~g} / \mathrm{kg} \mathrm{DM}$ for kale, 180-240 g/kg DM for forage rape and turnip, and 165$196 \mathrm{~g} / \mathrm{kg}$ DM for swede $(12,17,18,18-20)$, while the content of readily fermentable carbohydrates was $253 \mathrm{~g} / \mathrm{kg}$ DM for kale, 285 $\mathrm{g} / \mathrm{kg}$ DM for forage rape, $334 \mathrm{~g} / \mathrm{kg}$ DM for turnip, and $370 \mathrm{~g} / \mathrm{kg}$ DM for swede (18). Among readily fermentable carbohydrates, the content of pectin is about 69-94 g/ $\mathrm{kg}$ DM (18), the content of sugars (raffinose, sucrose, glucose, fructose) and starch is 205 $\mathrm{g} / \mathrm{kg}$ DM for kale, $138 \mathrm{~g} / \mathrm{kg}$ DM for forage rape, $194 \mathrm{~g} / \mathrm{kg}$ DM for turnip, and $283 \mathrm{~g} / \mathrm{kg} \mathrm{DM}$ for swede (17). The content of crude protein is $130-162 \mathrm{~g} / \mathrm{kg}$ DM for bulb brassicas and $167-193 \mathrm{~g} / \mathrm{kg}$ DM for leafy brassicas (18). The low content of NDF and the high content of readily fermentable carbohydrates lead to a high ruminal degradation rate $(21,22)$, a high DM digestibility (810$890 \mathrm{~g} / \mathrm{kg}$ ), and a high metabolizable energy content (12.1-14.1 $\mathrm{MJ} / \mathrm{kg} \mathrm{DM}$ ) and thus have a high feeding value for ruminants $(12,18)$. As a result, these crops have been applied in farming practice in sheep $(23,24)$, beef cattle $(25)$, dairy cows $(25-27)$, and deer (12).

Research on the use of brassica forages for the mitigation of $\mathrm{CH}_{4}$ emissions from ruminants began in New Zealand. Sun et al. (18) reported for the first time that four common forage brassica crops in New Zealand kale, turnip, rape, and swede fed to sheep in winter resulted in lower $\mathrm{CH}_{4}$ yield $\left(\mathrm{CH}_{4}\right.$ emissions per unit of DM intake) by $10,6,25$, and $23 \%$, respectively, compared with the control perennial ryegrass.

A series of animal experiments were conducted after this study (28). These experiments were conducted under various conditions including short- vs. long-term feeding (29), indoor feeding vs. grazing (30), winter vs. summer varieties (31), different brassica types (32), and primary growth vs. regrowth (32). Under these conditions, $\mathrm{CH}_{4}$ emissions were always lower than the control perennial ryegrass-based pasture. When forage rape was mixed with perennial ryegrass to form mixed diets with gradual inclusion levels for sheep, $\mathrm{CH}_{4}$ yields declined linearly with the increase in the proportion of forage rape in the diet (33). Heifers fed forage rape also emitted less $\mathrm{CH}_{4}$ than those fed perennial ryegrass-based pasture (34). A study conducted in Australia showed that feeding dairy cows with brassica forage (B. napus cv. Winfred) during summer resulted in a $21 \%$ lower $\mathrm{CH}_{4}$ yield than feeding chicory (Cichorium intybus) (35). It was concluded that both sheep and cattle fed different forage brassica crops in different seasons as a sole diet, or as a component of a mixed diet, under housed feeding or grazing conditions, emit low $\mathrm{CH}_{4}$ to varying degrees, and the mitigation effect does not disappear with extended feeding.

\section{SECONDARY METABOLITES IN FORAGE BRASSICA MAY CONTRIBUTE TO LOW METHANE EMISSIONS}

The known mechanisms for the mitigation of enteric $\mathrm{CH}_{4}$ emissions mainly include the manipulation of rumen microbiota by methods such as the addition of $\mathrm{CH}_{4}$ inhibitors, and the manipulation of fermentation substrates of rumen microorganisms, such as altering dietary composition and providing electron acceptors $(10,36)$. These mechanisms cannot fully explain the low $\mathrm{CH}_{4}$ emissions with forage brassicas.

Lower $\mathrm{CH}_{4}$ yields from forage brassica were associated with differences in the rumen microbiota compared to perennial ryegrass, with a proposal for shifts in fermentation to more propionate and less hydrogen, resulting in less $\mathrm{CH}_{4}$ 
(29). However, the factors resulting in this rumen microbial community difference are not fully understood. A multiple regression analysis of the conventional nutrients of brassica crops and $\mathrm{CH}_{4}$ yield showed that only water content among these nutrients had a weak correlation with emissions (37). Nitrate and sulfate can be used as electron acceptors to reduce $\mathrm{CH}_{4}$ emissions (38), but their contents in forage brassica crops vary widely $(12,39)$. Even the highest contents in brassica crops explain but a small proportion of the reduction in $\mathrm{CH}_{4}$ emissions $(18,29)$. A meta-analysis of the relationship between rumen fermentation parameters and $\mathrm{CH}_{4}$ yield in sheep showed that fermentation type, as indicated by the ratio of acetate to propionate and butyrate, had a limited effect (40). A low rumen $\mathrm{pH}$ is associated with low methanogenesis $(41,42)$. While the rumen $\mathrm{pH}$ was low in sheep fed forage rape (29), a study in which rumen $\mathrm{pH}$ of forage rape-fed sheep was manipulated by adding sodium carbonate did not suggest that the low $\mathrm{CH}_{4}$ yield results totally from low rumen $\mathrm{pH}$ (43). The rumen microbial community of sheep fed forage rape differed greatly from that of sheep fed perennial ryegrass. For example, there were increased abundances of Selenomonas and Sharpea, whereas Selenomonas is known to produce acetate and propionate or lactate and Sharpea are lactate producers (44) and linked to low $\mathrm{CH}_{4}$ via a proposed pathway (45). However, the importance of altered microbial community in low $\mathrm{CH}_{4}$ emissions might be limited (29). In summary, although rumen fermentation type has a limited effect, and some factors such as conventional nutrients, nitrate and sulfate in forage brassica can be ruled out for the explanation of low $\mathrm{CH}_{4}$ emissions with forage brassica, the reason why is still unclear.

It has been reported that chicory $(46,47)$ and white clover (Trifolium repens) (48) do not result in lower $\mathrm{CH}_{4}$ emissions compared with perennial ryegrass-based pasture. Chicory, white clover and forage brassicas are dicotyledonous plants. The conventional nutritional composition is similar, but the secondary metabolites between them are different. The discrepancy in $\mathrm{CH}_{4}$ emissions from these plants suggests that secondary metabolites in forage brassicas might play a role in mitigation. Glucosinolates (GSLs) and S-methyl-Lcysteine sulfoxide (SMCO) are two types of plant secondary metabolites which are widely present in Brassica plants $(49,50)$. Therefore, these two types of compounds should be a focus for exploring the mechanisms underlying the low $\mathrm{CH}_{4}$ emissions with brassica forages.

\section{SECONDARY METABOLITES IN FORAGE BRASSICAS}

Concerns over GSLs and SMCO mainly due to anti-nutritional effects in animals $(12,51)$ and possible beneficial effects to human health $(52,53)$ contributed to the need for this review. Glucosinolates are a class of sulfur-containing anionic hydrophilic plant secondary metabolites whose core structure is $\beta$-D-glucose linked to a sulfonate aldoxime group (Figure 1), and a side chain derived from amino acids (54).

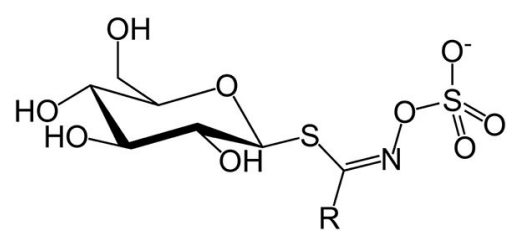

FIGURE 1 | Glucosinolate structure (the side group R varies).

Glucosinolates have no physiological activity per se, and after combination with $\beta$-glucosidase (also known as myrosinase), they are degraded to a variety of biologically active substances, which have toxic effects on herbivores and also function as repellents (55). Glucosinolates and $\beta$-glucosidase are present in different cells or different areas of the same cell in plants, and they react when the plant is mechanically damaged or chewed by the animal. The products of the breakdown are mainly isothiocyanate (ITC), thiocyanate, nitrile, epithionitrile and oxzolidine-2-thione, of which ITC is the most important product (Figure 2) (52).

There are extensive studies of GSLs in brassica vegetables and oil crops (57), but there are few studies on brassica forages. Velasco et al. (58) found that GSL profile differs greatly in rape varieties for the use as vegetables, oilseeds and feeds. Knowledge gained from brassicas for other uses cannot be applied directly to brassica crops for feed use. It has been reported that there are many types of GSLs in brassica forages, up to 18 , but the contents of individual GSLs vary greatly (Table 1). Among them, 3-4 GSLs are predominant, accounting for more than $80 \%$ of the total content. Each brassica forage crop has its own predominant GSLs, but glucobrassicanapin is generally more than $40 \%$ of the total GSL content in forage rape, swede and turnip, and sinigrin exceeds $40 \%$ of the total GSL content in kale (18). The breakdown products of GSLs in brassica forages have been reported (59) and knowledge about them is generally derived from research results from brassica crops used for other purposes (52). Rapeseed cake contains a large amount of GSLs and the structure, breakdown products and their effects on animals have been extensively reviewed (56). Glucosinolates produce mainly ITC and nitriles in the rumen. During digestion, about $21-41 \%$ of GSLs in kale leaves are converted to nitriles, $37 \%$ for swede leaves and 50\% for swede bulbs (12). Nitriles are not degraded for at least $23 \mathrm{~h}$ after sheep consume kale, but completely degraded within $4 \mathrm{~h}$ for swede bulbs and leaves.

The non-protein amino acid SMCO is about $1-2 \%$ by dry weight in brassica plants (60). The contents of SMCO vary among forage brassica species and is especially high in kale (12). The SMCO contents are also affected by fertilizer application (12), silage making (61) and harvesting (62). When plant tissues are broken, cysteine sulfoxide lyases in the vacuole are released, resulting in decomposition of SMCO into ammonia, pyruvate and methanesulphenic acid (60). Complete conversion of SMCO to dimethyl disulphide occurs in the rumen, and dimethyl 


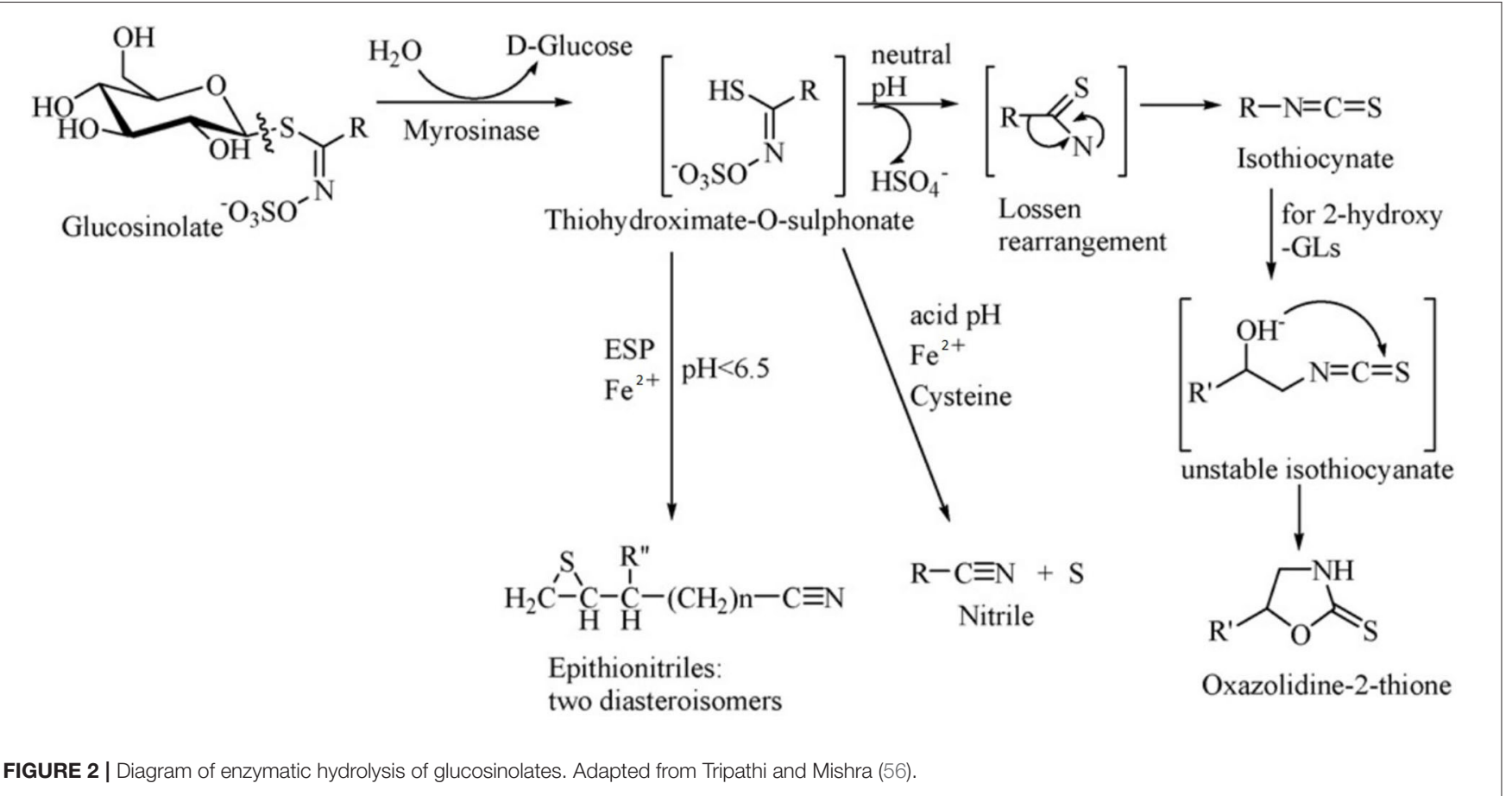

TABLE 1 | Concentration of total glucosinolates (GSLS) and proportion of individual GSLs in brassica forages ${ }^{a}$.

\begin{tabular}{|c|c|c|c|c|}
\hline Items & Kale (Brassica oleracea) & Rape (B. napus) & Swede (B. napus) & Turnip (B. campestris) \\
\hline $\begin{array}{l}\text { Total glucosinolate } \\
\text { ( } \mu \mathrm{mol} / \mathrm{kg} \text { dry matter) }\end{array}$ & 229.3 & 308.4 & 803.8 & 1218.1 \\
\hline \multicolumn{5}{|c|}{ Proportion of individual GSLs in the total GSLs } \\
\hline Sinigrin & 40.6 & 0.0 & 0.0 & 0.0 \\
\hline Glucobrassicanapin & 0.1 & 44.4 & 40.0 & 44.8 \\
\hline Epiprogoitrin & 23.6 & 17.7 & 16.9 & 13.1 \\
\hline Gluconapin & 17.5 & 10.5 & 14.0 & 22.2 \\
\hline Gluconasturtiin & 0.8 & 3.6 & 14.6 & 6.9 \\
\hline Gluconapoleiferin & 0.0 & 8.3 & 4.9 & 7.1 \\
\hline Glucoraphanin & 8.0 & 0.7 & 0.8 & 0.3 \\
\hline Glucobrassicin & 7.4 & 5.4 & 0.2 & 0.2 \\
\hline Glucoalyssin & 0.3 & 4.7 & 2.4 & 1.0 \\
\hline Progoitrin & 0.0 & 3.2 & 3.0 & 3.3 \\
\hline Sinalbin & 1.7 & 1.5 & 0.7 & 0.4 \\
\hline Glucoiberin & 0.0 & 0.0 & 1.6 & 0.4 \\
\hline Glucoerucin & $n d^{b}$ & nd & 0.9 & 0.2 \\
\hline Glucotropaeolin & 0.0 & 0.0 & 0.0 & 0.0 \\
\hline 4-hydroxyglucobrassicin & 0.0 & nd & 0.0 & 0.0 \\
\hline Glucobarbarin & nd & nd & 0.0 & 0.0 \\
\hline Glucoraphenin & nd & nd & 0.0 & nd \\
\hline Glucosibarin & nd & nd & 0.0 & nd \\
\hline
\end{tabular}

${ }^{a}$ Adapted from Sun et al. (18).

${ }^{b}$ nd, not detected.

disulphide inactivates proteins by combining the sulphdryl group in proteins. For example, dimethyl disulphide can reduce the content of hemoglobin, and even cause anemia, and can also affect the production of host and microbial proteins in the body. S-methyl-L-cysteine sulfoxide can increase ghrelin and thyroid hormones in the plasma, which can stimulate the body's 
protein synthesis to replace the protein inactivated by dimethyl sulfoxide (12).

\section{SECONDARY METABOLITES MIGHT NOT DIRECTLY INHIBIT METHANOGENS}

Jayanegara et al. (63) found that Brassica crassifolia resulted in $25 \%$ less $\mathrm{CH}_{4}$ emissions than grass hay in an in vitro batch culture study. Dillard et al. (64) studied the methanogenesis of brassica forage crops using a continuous fermentation system with half of the culture substrate as Dactylis glomerata and the other half as forage rape, oilseed rape (B. napus), turnip or annual ryegrass ( $L$. multflorum). They found that $\mathrm{CH}_{4}$ production from forage brassica crops was lower than from annual ryegrass. The conclusion was the same when the emissions were expressed as per unit of incubated organic matter, neutral detergent fiber, digestible organic matter and digestible neutral detergent fiber. Jayanegara et al. (63) and Dillard et al. (64) speculated that the plant secondary metabolites in brassica crops play a role as methanogen inhibitors in the reduction of $\mathrm{CH}_{4}$ production. In an in vitro study conducted by Durmic et al. (65), a hybrid of kale and turnip (B. napus cv. Winfred) and turnip produced $30 \%$ less $\mathrm{CH}_{4}$ in comparison with the control arrowhead clover (Trifolium vesiculosum), but there were great variations among different cultivars of the same forage species. Broccoli ( $B$. oleracea) and a hybrid of turnip and forage rape (B. campestris $\times B$. napus) were not significantly different from arrowhead clover in $\mathrm{CH}_{4}$ production. The characteristic phenomenon of methanogen inhibition in vitro is the release and accumulation of a large amount of hydrogen (66). These studies did not measure the concentration of hydrogen emitted, which makes it difficult to determine if methanogen inhibitors were present in these feedstuffs. Sun and Pacheco (32) did not find a significant difference in methanogenesis between forage brassicas, including kale, turnip, forage rape and swede, and perennial ryegrass in an in vitro study, and significant emissions and accumulation of hydrogen were not observed, suggesting that no methanogen inhibitor exists in brassica forages.

Researchers have also used GSLs and their breakdown products directly to test for effects on $\mathrm{CH}_{4}$ emission in in vitro rumen fermentation studies. The addition of GSLs extracted from mustard cake at doses of $0,9,18,27$ and $45 \mathrm{mg} / 100 \mathrm{~mL}$ did not adversely affect the total short-chain fatty acid (SCFA) concentration and microbial activity, but the proportion of $\mathrm{CH}_{4}$ in the total gas production increased with the amount dosed, indicating no inhibitory effects (67). Reduced $\mathrm{CH}_{4}$ production and hydrogen accumulation were observed when allyl isothiocyanate, a breakdown product of sinigrin, was added at doses of 48 and $96 \mathrm{mg} / \mathrm{L}(68)$ or at a dose of $75 \mathrm{mg} / \mathrm{L}$ (69) for in vitro incubation. Similar results were also obtained in in vitro studies with allyl isothiocyanate-containing mustard seeds (70) or mustard cake (71). However, the concentrations of GSL breakdown products in these studies were much higher than those that are present in brassica forages as a sole diet in natural conditions. There was no significant difference in $\mathrm{CH}_{4}$ production between broccoli cultivars with a high or low

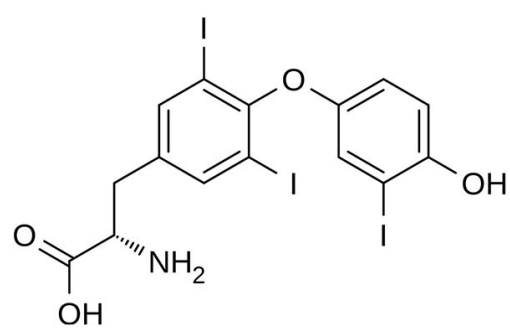

FIGURE 3 | Triiodothyronine structure.

content of GSLs as substrates for in vitro culture (65). In an animal study, although $\mathrm{CH}_{4}$ emissions were not measured, the ruminal concentrations of SCFAs and the ratio of acetate to propionate did not differ in the rumen of steers fed either highor low-GSL rapeseed (Brassica napus cv Bridger and DwarfEssex) forage (72). The effects of SMCO on $\mathrm{CH}_{4}$ emissions have not been reported. According to the literature mentioned above, GSLs, SMCO, and their breakdown products are unlikely to be methanogen inhibitors.

\section{GLUCOSINOLATES MIGHT RESULT IN LOW METHANE EMISSIONS VIA ANIMAL PHYSIOLOGICAL PARAMETERS}

\section{Effects of Secondary Metabolites in Brassica Forages on Triiodothyronine}

Triiodothyronine $\left(\mathrm{T}_{3}\right)$ (Figure 3 ) and thyroxine $\left(\mathrm{T}_{4}\right)$ are two thyroid hormones produced and released by the thyroid gland (73). Thyroxine can be converted to $\mathrm{T}_{3}$, which is three to four times more metabolically active than $\mathrm{T}_{4}(74)$. The thyroid hormones in the blood are mainly present in the form of $\mathrm{T}_{4}$ with a ratio of $T_{4}$ to $T_{3}$ at $\sim 14: 1$. The major fraction of the thyroid hormones is bound with transport proteins, and a small fraction is free and biologically active. Thus, the concentrations of free thyroid hormones, especially free $\mathrm{T}_{3}$, are measured as indicators of the hormone activity.

Feeding brassica forages or diets containing GSLs and their breakdown products can affect animal thyroid function and alter thyroid hormone secretion (56, 75-79). For example, feeding turnip (Brassica rapa L.) and kale (B. oleracea L. var. acephala DC) to fattening lambs can increase the concentrations of $\mathrm{T}_{3}$ and $\mathrm{T}_{4}$ in serum (76). Feeding a diet containing a high content of GSLs to calves resulted in a quadratically increased serum $\mathrm{T}_{4}$ concentration, although $\mathrm{T}_{3}$ concentration remained within the normal physiological range (79). Diets contained GSLs affect thyroid function in many animal species (56), including pigs (80), mares (81), turkeys (82), hens (83), and turbots (84), suggesting that effects of GSLs on thyroid function are not unique to ruminants, but universal in a wide range of animal species.

The mechanisms of how GSLs affect thyroid hormones in ruminant animals are not clear, but it is believed to be related to iodine and selenium (74). Iodine is a component of the hormones, while deiodinases involved in the conversion of $\mathrm{T}_{4}$ 
to $\mathrm{T}_{3}$ are selenium-containing enzymes, and thus selenium is essential for $\mathrm{T}_{3}$ production. It is recommended to supplement sheep grazing kale with iodine to lighten the effects of GSLs (75). The impacts of GSLs present in the diet can be counteracted with the supplementation of iodine or iodine plus selenium to sheep $(77,85)$. Iodine uptake by the thyroid can be inhibited by GSLs and their breakdown products such as goitrin and isothiocyanates $(52,86,87)$. In a rat study, nitriles, another group of GSL breakdown products were considered to result in the enlargement of the thyroid (88).

Ruminal microorganisms break SMCO down into dimethyl disulfide, causing anemia (60), but activities on thyroid physiology were not reported. It is unlikely that SMCO has an effect on blood $\mathrm{FT}_{3}$ concentration.

\section{Effects of Free Triiodothyronine on Digesta Retention Time}

Thyroid hormones are associated with digesta excretion from the rumen. Sheep exposed to a cold environment $\left(2-5^{\circ} \mathrm{C}\right)$ had a 1.5 times greater $\mathrm{T}_{3}$ concentration in plasma (152 vs. $62 \mathrm{ng} / 100 \mathrm{~mL}$ ) and a $6.2 \mathrm{~h}$ shorter rumen mean retention time $(11.8$ vs. $18 \mathrm{~h})$ than those exposed to a warm environment $\left(22-25^{\circ} \mathrm{C}\right)(89)$. A greater $\mathrm{T}_{3}$ concentration ( $103 \mathrm{vs.} 21 \mathrm{ng} / 100 \mathrm{~mL}$ ) in sheep plasma resulting from a daily injection of $0.25 \mathrm{mg} \mathrm{T}_{3}$ also reduced the rumen mean retention time (17.8 vs. $20.4 \mathrm{~h}$ ) (89). The removal of the thyroid gland from sheep housed at $22-25^{\circ} \mathrm{C}$ caused $\mathrm{T}_{3}$ concentration to drop from $38 \mathrm{ng} / 100 \mathrm{~mL}$ to zero in plasma and the rumen mean retention time extended from 17.9 to $23.6 \mathrm{~h}$ (89). In a study with mature ewes by Lourenço et al. (90), it was observed that liquid rumen retention time was 18.5 vs. $26.3 \mathrm{~h}$, while $\mathrm{T}_{3}$ concentration was $83-99$ vs. $59-67 \mathrm{ng} / 100 \mathrm{~mL}$ at high $\left(25^{\circ} \mathrm{C}\right)$ and low $\left(11^{\circ} \mathrm{C}\right)$ temperatures, respectively (90). When mature wethers were injected with $300 \mu \mathrm{g}$ of $\mathrm{FT}_{3}$ every 2 days, the blood $\mathrm{FT}_{3}$ concentration increased from 16 to $54 \mathrm{ng} / 100 \mathrm{~mL}$, and digesta retention time in the whole digestive tract was reduced by $4 \mathrm{~h}$ (91).

The mechanism of thyroid hormones affecting rumen physiology is unknown, but in the human body, thyroid disorders are associated with gastrointestinal dysfunction (92). It is proposed that thyroid hormones affect gut motility either directly or via a central stimulatory effect on the chemoreceptor trigger zone.

\section{Effects of Digesta Retention Time on Methane Emissions}

Pinares-Patino et al. (93) found that short digesta mean retention time, especially in the particulate phase, was associated with low $\mathrm{CH}_{4}$ production in sheep fed alfalfa. In a study on mature ewes divergently selected for high and low $\mathrm{CH}_{4}$ yields, a shorter mean retention time of particulate and liquid digesta was associated with low $\mathrm{CH}_{4}$ yield (94). This association was further confirmed in a recent study by Bond et al. (95), who measured rumen digesta flow and $\mathrm{CH}_{4}$ yield using open-circuit respiration chambers in ewes phenotypically differing in $\mathrm{CH}_{4}$ emissions. Using simulation with mathematical models, Huhtanen et al. (96) also demonstrated that dairy cows and sheep with short digesta retention times emit less $\mathrm{CH}_{4}$.
Low- $\mathrm{CH}_{4}$ yielding sheep not only had smaller rumens (97), but these sheep had different rumen microbial communities compared to high- $\mathrm{CH}_{4}$ yielding sheep (98). Detailed studies of these sheep indicated that their microbial communities were fermenting feed using different pathways that led to the observed lower $\mathrm{CH}_{4}$ yields (45), and these differences were attributed to faster passage rates through the rumen of the low- $\mathrm{CH}_{4}$ yield sheep $(45,99)$. Furthermore, a recent study integrating rumen wall transcriptome data and $\mathrm{CH}_{4}$ phenotypes found that a set of rumen muscle genes is involved in cell junctions, which could be potential regulators of rumen digesta retention time and thus could be a molecular mechanism for the association of rumen digesta retention time with $\mathrm{CH}_{4}$ yield in sheep (100).

\section{Effects of Free Triiodothyronine on Methane Emissions}

Elevating serum $\mathrm{FT}_{3}$ by intramuscular injection of $\mathrm{FT}_{3}$ in sheep can result in shorter digesta retention time and consequently reduce $\mathrm{CH}_{4}$ yield by $8 \%$ (91). An increase in blood $\mathrm{FT}_{3}$ concentration in sheep a result of a decrease in ambient temperature also lead to reduced digesta mean retention time and decreases $\mathrm{CH}_{4}$ yield (101).

\section{Hypothesis}

Based on the literature reviewed here, a hypothesis is proposed that under normal farming conditions, the secondary metabolites GSLs and/or their breakdown products in brassica forage crops do not directly inhibit the growth and activity of methanogens, but increase blood $\mathrm{FT}_{3}$ concentration in ruminants, resulting in a decrease in digesta mean retention time in the rumen, thereby reducing $\mathrm{CH}_{4}$ emissions (Figure 4).

\section{CONCLUDING REMARKS}

Climate change is a topic of increasing concern in the world. Anthropogenic activities, including industrial and agricultural production, emit greenhouse gases that are the main drivers of climate change. Methane is an important greenhouse gas, and ruminal fermentation of feed is an important source of $\mathrm{CH}_{4}$. Exploring simple, effective and low-cost approaches without side effects to mitigate $\mathrm{CH}_{4}$ emissions from ruminants is supported by the governments of most countries. Reducing $\mathrm{CH}_{4}$ emissions from ruminants not only helps to slow down climate change but also improves the feed energy efficiency of ruminants. Therefore, the study of the ruminant $\mathrm{CH}_{4}$ emission mechanism is of great significance.

This article puts forward a hypothesis that the secondary metabolites of brassica forage crops GSL and its metabolites can elevate the concentration of $\mathrm{FT}_{3}$ in ruminants and lead to a reduction in mean ruminal digesta retention time, thereby reducing $\mathrm{CH}_{4}$ emissions. This is a new mechanism in which the mitigation of $\mathrm{CH}_{4}$ emissions is achieved by manipulating ruminant physiological parameters and goes beyond the existing mechanisms which limit the mitigation to the manipulation of rumen microorganisms and their substrates.

If this hypothesis is confirmed, it will be a new direction for the mitigation of $\mathrm{CH}_{4}$ emissions from ruminants and will expand research to a new field with great research value. Further 
Hypothesis

GSL and/or breakdown products

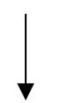

Free triiodothyronine $\left(\mathrm{FT}_{3}\right)$

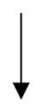

Rumen mean retention time

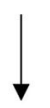

Methane emissions
Supporting references

(Barry and Duncan, 1983; Cox-Ganser et al., 1994; Trávníček et al., 2001;

Okulicz et al., 2002; Tripathi and Mishra, 2007; Ravichandiran et al., 2008)

(Kennedy et al., 1977; Lourenço et al. 2010; Barnett et al., 2012)

(Pinares-Patino et al., 2003; Goopy et al., 2014; Huhtanen et al., 2016; Bond

et al., 2019)

FIGURE 4 | Diagram of the proposed hypothesis and supporting references.

questions to be answered include how individual GSLs affect $\mathrm{FT}_{3}$ and $\mathrm{CH}_{4}$ emissions differently, what the molecular mechanism of GSLs affecting the function of the thyroid gland and the secretion of $\mathrm{FT}$ is, how $\mathrm{FT}_{3}$ affect rumen digesta retention time, how $\mathrm{FT}_{3}$ affect rumen muscle genes, etc. As brassica forages are common forages, this hypothesis is of great value in ruminant livestock methane abatement studies. Approaches to enhanced mitigation efficiency could be found by a deep understanding of these questions.

\section{AUTHOR CONTRIBUTIONS}

The author confirms being the sole contributor of this work and has approved it for publication.

\section{REFERENCES}

1. Myhre G, Shindell D, Bréon FM, Collins W, Fuglestvedt J, Huang J, et al. Anthropogenic and natural radiative forcing. In: Stocker TF, Qin D, Plattner GK, Tignor M, Allen SK, Boschung J, Nauels A, Xia Y, Bex V, Midgley PM, editors. Climate Change 2013: The Physical Science Basis. Contribution of Working Group I to the Fifth Assessment Report of the Intergovernmental Panel on Climate Change. Cambridge, UK; New York, NY: Cambridge University Press (2013).

2. Kirschke S, Bousquet P, Ciais P, Saunois M, Canadell JG, Dlugokencky EJ, et al. Three decades of global methane sources and sinks. Nat Geosci. (2013) 6:813-23. doi: 10.1038/ngeo1955

3. Knapp JR, Laur GL, Vadas PA, Weiss WP, Tricarico JM. Invited review: enteric methane in dairy cattle production: quantifying the opportunities and impact of reducing emissions. J Dairy Sci. (2014) 97:3231-61. doi: 10.3168/jds.2013-7234

4. Appuhamy JA, France J, Kebreab E. Models for predicting enteric methane emissions from dairy cows in North America, Europe, and Australia and New Zealand. Glob Chang Biol. (2016) 22:3039-56. doi: 10.1111/gcb.13339

5. Cherdthong A, Prachumchai R, Wanapat M, Foiklang S, Chanjula P. Effects of supplementation with royal poinciana seed meal (Delonix regia) on ruminal fermentation pattern, microbial protein synthesis, blood metabolites

\section{FUNDING}

This work is supported by Jilin Agricultural Science and Technology University under a Startup Research Program (Grant No. 2018:5001) and by the Development of Science and Technology of Jilin Province under an Innovation Platform Program (Grant No. 20200602016ZP).

\section{ACKNOWLEDGMENTS}

The author thanks Drs. Adrian Molenaar and Peter Janssen for critical readings and valuable suggestions.

and mitigation of methane emissions in native thai beef cattle. Animals. (2019) 9:625. doi: 10.3390/ani9090625

6. Huhtanen P, Cabezas-Garcia EH, Utsumi S, Zimmerman S. Comparison of methods to determine methane emissions from dairy cows in farm conditions. J Dairy Sci. (2015) 98:3394-409. doi: 10.3168/jds.2014-9118

7. Pickering NK, Oddy VH, Basarab J, Cammack K, Hayes B, Hegarty RS, et al. Animal board invited review: genetic possibilities to reduce enteric methane emissions from ruminants. Animal. (2015) 9:1431-40. doi: 10.1017/S1751731115000968

8. Patra A, Park T, Kim M, Yu Z. Rumen methanogens and mitigation of methane emission by anti-methanogenic compounds and substances. J Anim Sci Biotechnol. (2017) 8:271-88. doi: 10.1186/s40104-017-0145-9

9. Vallejo-Hernández LH, Elghandour MMY, Greiner R, Anele UY, RivasCáceres RR, Barros-Rodríguez $\mathrm{M}$, et al. Environmental impact of yeast and exogenous xylanase on mitigating carbon dioxide and enteric methane production in ruminants. J Clean Prod. (2018) 189:40-6. doi: 10.1016/j.jclepro.2018.03.310

10. Beauchemin KA, Ungerfeld EM, Eckard RJ, Wang M. Review: fifty years of research on rumen methanogenesis: lessons learned and future challenges for mitigation. Animal. (2020) 14:s2-16. doi: 10.1017/S1751731119003100

11. Goopy JP. Creating a low enteric methane emission ruminant: what is the evidence of success to the present and prospects for developing 
economies? Anim Prod Sci. (2019) 59:1769-76. doi: 10.1071/AN 18457

12. Barry TN. The feeding value of forage brassica plants for grazing ruminant livestock. Anim Feed Sci Technol. (2013) 181:15-25. doi: 10.1016/j.anifeedsci.2013.01.012

13. Rawnsley RP, Chapman DF, Jacobs JL, Garcia SC, Callow MN, Edwards GR, et al. Complementary forages-integration at a whole-farm level. Anim Prod Sci. (2013) 53:976-87. doi: 10.1071/AN12282

14. Stewart A, Kerr G, Lissamann W, Rowarth JS. Pasture and Forage Plants for New Zealand. Dunedin: New Zealand Grassland Association (2014).

15. Jeromela AM, Mikić AM, Vujić S, Cupina B, Krstić D, Dimitrijević A, et al. Potential of legume-brassica intercrops for forage production and green manure: encouragements from a temperate southeast European environment. Front Plant Sci. (2017) 8:312. doi: 10.3389/fpls.2017.00312

16. de Ruiter JM, Fletcher A, Maley S, Sim R, George M. Aiming for $45 \mathrm{t} / \mathrm{ha}$ per annum: yield of supplementary feed crops grown in sequences designed for maximum productivity. Proc N Z Grasslands Assoc. (2009) 71:07-116. doi: 10.33584/jnzg.2009.71.2760

17. Keim JP, Gandarillas M, Benavides D, Cabanilla J, Pulido RG, Balocchi OA, et al. Nutrient concentrations and profile of non-structural carbohydrates vary among different Brassica forages. Anim Prod Sci. (2020) 60:1503-13. doi: 10.1071/AN19472

18. Sun XZ, Waghorn GC, Hoskin SO, Harrison SJ, Muetzel S, Pacheco D. Methane emissions from sheep fed fresh brassicas (Brassica spp.) compared to perennial ryegrass (Lolium perenne). Anim Feed Sci Technol. (2012) 176:107-16. doi: 10.1016/j.anifeedsci.2012.07.013

19. McCartney D, Fraser J, Ohama A. Potential of warm-season annual forages and Brassica crops for grazing: a Canadian review. Can J Anim Sci. (2009) 89:431-40. doi: 10.4141/CJAS09002

20. Daza J, Benavides D, Pulido R, Balocchi O, Bertrand A, Keim J. Rumen in vitro fermentation and in situ degradation kinetics of winter forage brassicas crops. Animals. (2019) 9:904. doi: 10.3390/ani9110904

21. Keim JP, Cabanilla J, Balocchi OA, Pulido RG, Bertrand A. In vitro fermentation and in situ rumen degradation kinetics of summer forage brassica plants. Anim Prod Sci. (2018) 59:1271-80. doi: 10.1071/AN17534

22. Zhao N, Yang XH, Wei JT, Guo WZ, Chen F, Zhou GS, et al. Nutritional composition of forage rape and its rumen degradation characteristics in goats. Acta Pratacult Sin. (2020) 29:50-7. doi: 10.11686/cyxb2019376

23. Reid RL, Puoli JR, Jung GA, Cox-Ganser JM, McCoy A. Evaluation of Brassicas in grazing systems for sheep: I. quality of forage and animal performance. J Anim Sci. (1994) 72:1823-31. doi: 10.2527/1994.7271823x

24. Raeside MC, Byron J, Cameron F, Macdonald C, Partington DL, Kearney GA, et al. Spring-sown winter-type canola (Brassica napus) as summer-autumn forage for sheep production in southern Australia. Anim Prod Sci. (2020). doi: 10.1071/AN19182. [Epub ahead of print].

25. Dillard SL, Billman ED, Soder KJ. Assessment of forage brassica species for dairy and beef-cattle fall grazing systems. Appl Anim Sci. (2020) 36:157-66. doi: 10.15232/aas.2019-01921

26. Castillo-Umaña M, Balocchi O, Pulido R, Sepúlveda-Varas P, Pacheco D, Muetzel S, et al. Milk production responses and rumen fermentation of dairy cows supplemented with summer brassicas. Animal. (2020) 14:1-9. doi: 10.1017/S175173112000021X

27. Keim JP, Daza J, Beltrán I, Balocchi OA, Pulido RG, Sepúlveda-Varas P, et al. Milk production responses, rumen fermentation, and blood metabolites of dairy cows fed increasing concentrations of forage rape. J. Dairy Sci. (2020) 103:9054-66. doi: 10.3168/jds.2020-18785

28. Sun XZ, Pacheco D, Luo DW. Forage brassica: a feed to mitigate enteric methane emissions? Anim Prod Sci. (2016) 56:451-6. doi: 10.1071/AN15516

29. Sun X, Henderson G, Cox F, Molano G, Harrison SJ, Luo D, et al. Lambs fed fresh winter forage rape (Brassica napus L.) emit less methane than those fed perennial ryegrass (Lolium perenne L.), and possible mechanisms behind the difference. PLoS ONE. (2015) 10:e0119697. doi: 10.1371/journal.pone.0119697

30. Sun XZ, Hoogendoorn C, Luo J, Pacheco D. Greenhouse gas emissions from lambs grazing either forage rape or perennial ryegrass. In: Milestones 1.3. A report to Ministry for Primary Industries. Wellington: Ministry for Primary Industries (2013). p. 1-38.
31. Sun XZ, Maclean S, Luo DW, Pacheco D. Sheep fed five different summer forage brassicas emitted less methane than sheep fed perennial ryegrass/white clover pasture. Proc Austr Soc Anim Prod. (2014) 30:98.

32. Sun XZ, Pacheco D. (2014). Greenhouse gas emissions from lambs fed summer forage brassicas or pasture. In: Milestone 4. Report to the Ministry for Primary Industries. Wellington: Ministry for Primary Industries (2014). p. 1-13.

33. Sun XZ, Sandoval E, Pacheco D. Effects of forage rape inclusion level in the diet on methane emissions from sheep. Proc $N$ Z Soc Anim Prod. (2015) 75:64-6.

34. Sun XZ, Hoogendoorn C, Luo J, Pacheco D. Greenhouse gas emissions from cattle fed winter forage rape or pasture. In: Milestone 9. Report to the Ministry for Primary Industries. Wellington: Ministry for Primary Industries (2015). p. $1-41$.

35. Williams SRO, Moate PJ, Deighton MH, Hannah MC, Wales WJ, Jacobs JL. Milk production and composition, and methane emissions from dairy cows fed lucerne hay with forage brassica or chicory. Anim Prod Sci. (2016) 56:304-11. doi: 10.1071/AN15528

36. Hristov AN, Oh J, Firkins JL, Dijkstra J, Kebreab E, Waghorn G, et al. SPECIAL TOPICS-Mitigation of methane and nitrous oxide emissions from animal operations: I. a review of enteric methane mitigation options. J Anim Sci. (2013) 91:5045-69. doi: 10.2527/jas.2013-6583

37. Pacheco D, Waghorn GC, Janssen PH. Decreasing methane emissions from ruminants grazing forages: a fit with productive and financial realities? Anim Prod Sci. (2014) 54:1141-54. doi: 10.1071/AN14437

38. van Zijderveld SM, Gerrits WJ, Apajalahti JA, Newbold JR, Dijkstra J, Leng RA, et al. Nitrate and sulfate: effective alternative hydrogen sinks for mitigation of ruminal methane production in sheep. J Dairy Sci. (2010) 93:5856-66. doi: 10.3168/jds.2010-3281

39. Fletcher AL, Chakwizira E. Nitrate accumulation in forage brassicas. $N Z J$ Agric Res. (2012) 55:413-9. doi: 10.1080/00288233.2012.672428

40. He YH, Sun XZ, You PH. Animal, feed and rumen fermentation attributes associated with methane emissions from sheep fed brassica crops. J Anim Physiol Anim Nutr. (in press).

41. Van Kessel JAS, Russell JB. The effect of $\mathrm{pH}$ on ruminal methanogenesis. FEMS Microbiol Ecol. (1996) 20:205-10. doi: 10.1111/j.1574-6941.1996.tb00319.x

42. Hünerberg M, McGinn SM, Beauchemin KA, Entz T, Okine EK, Harstad $\mathrm{OM}$, et al. Impact of ruminal pH on enteric methane emissions. J Anim Sci. (2015) 93:1760-6. doi: 10.2527/jas.2014-8469

43. Sun XZ, Harland R, Pacheco D. Effect of altering ruminal $\mathrm{pH}$ by dietary buffer supplementation on methane emissions from sheep fed forage rape. Animal. (2020) 14:952-62. doi: 10.1017/S1751731119002799

44. Kumar S, Treloar BP, Teh KH, McKenzie CM, Henderson G, Attwood GT, et al. Sharpea and Kandleria are lactic acid producing rumen bacteria that do not change their fermentation products when co-cultured with a methanogen. Anaerobe. (2018) 54:31-8. doi: 10.1016/j.anaerobe.2018.07.008

45. Kamke J, Kittelmann S, Soni P, Li Y, Tavendale M, Ganesh S, et al. Rumen metagenome and metatranscriptome analyses of low methane yield sheep reveals a Sharpea-enriched microbiome characterised by lactic acid formation and utilisation. Microbiome. (2016) 4:56. doi: 10.1186/s40168-016-0201-2

46. Sun XZ, Hoskin SO, Muetzel S, Molano G, Clark H. Effects of forage chicory (Cichorium intybus) and perennial ryegrass (Lolium perenne) on methane emissions in vitro and from sheep. Anim Feed Sci Technol. (2011) 166-167:391-7. doi: 10.1016/j.anifeedsci.2011.04.027

47. Sun XZ, Hoskin SO, Zhang GG, Molano G, Muetzel S, Pinares-Patiño CS, et al. Sheep fed forage chicory (Cichorium intybus) or perennial ryegrass (Lolium perenne) have similar methane emissions. Anim Feed Sci Technol. (2012) 172:217-25. doi: 10.1016/j.anifeedsci.2011.11.007

48. Hammond KJ, Hoskin SO, Burke JL, Waghorn GC, Koolaard JP, Muetzel S. Effects of feeding fresh white clover (Trifolium repens) or perennial ryegrass (Lolium perenne) on enteric methane emissions from sheep. Anim Feed Sci Technol. (2011) 166-167:398-404. doi: 10.1016/j.anifeedsci.2011.04.028

49. Paul NK, Johnston TD, Eagles CF. Inheritance of S-methyl-L-cysteine sulphoxide and thiocyanate contents in forage rape (Brassica napus L.). Theor Appl Genet. (1986) 72:706-9. doi: 10.1007/BF00289013 
50. Sikorska-Zimny K, Beneduce L. The glucosinolates and their bioactive derivatives in Brassica: a review on classification, biosynthesis and content in plant tissues, fate during and after processing, effect on the human organism and interaction with the gut microbiota. Crit Rev Food Sci Nutr. (2020). doi: 10.1080/10408398.2020.1780193. [Epub ahead of print].

51. Paula EM, da Silva LG, Brandao VLN, Dai X, Faciola AP. Feeding canola, camelina, and carinata meals to ruminants. Animals. (2019) 9:704. doi: 10.3390/ani9100704

52. Prieto MA, López CJ, Simal-Gandara J. Glucosinolates: molecular structure, breakdown, genetic, bioavailability, properties and healthy and adverse effects. Adv Food Nutr Res. (2019) 90:305-50. doi: 10.1016/bs.afnr.2019.02.008

53. Quirante-Moya S, García-Ibañez P, Quirante-Moya F, Villaño D, Moreno DA. The role of brassica bioactives on human health: are we studying it the right way? Molecules. (2020) 25:1591. doi: 10.3390/molecules25071591

54. Fahey JW, Zalcmann AT, Talalay P. The chemical diversity and distribution of glucosinolates and isothiocyanates among plants. Phytochemistry. (2001) 56:5-51. doi: 10.1016/S0031-9422(00)00316-2

55. Bruce TJA. Glucosinolates in oilseed rape: secondary metabolites that influence interactions with herbivores and their natural enemies. Ann Appl Biol. (2014) 164:348-53. doi: 10.1111/aab.12128

56. Tripathi MK, Mishra AS. Glucosinolates in animal nutrition: a review. Anim Feed Sci Technol. (2007) 132:1-27. doi: 10.1016/j.anifeedsci.2006.03.003

57. BlaŽević I, Montaut S, Burčul F, Olsen CE, Burow M, Rollin P, et al. Glucosinolate structural diversity, identification, chemical synthesis and metabolism in plants. Phytochemistry. (2020) 169:112100. doi: 10.1016/j.phytochem.2019.112100

58. Velasco P, Soengas P, Vilar M, Cartea ME, Del Rio M. Comparison of glucosinolate profiles in leaf and seed tissues of different Brassica napus crops. J Am Soc Horticult Sci. (2008) 133:551-8. doi: 10.21273/JASHS.133.4.551

59. Forss DA, Barry TN. Observations on nitrile production during autolysis of kale and swedes, and their stability during incubation with rumen fluid. J Sci Food Agric. (1983) 34:1077-84. doi: 10.1002/jsfa.2740341007

60. Edmands WMB, Gooderham NJ, Holmes E, Mitchell SC. S-methyl-Lcysteine sulphoxide: the Cinderella phytochemical? Toxicol Res (Camb). (2013) 2:11-22. doi: 10.1039/C2TX20030A

61. Fales SL, Gustine DL, Bosworth SC, Hoover RJ. Concentrations of glucosinolates and S-methylcysteine sulfoxide in ensiled rape (Brassica napus L.). J Dairy Sci. (1987) 70:2402-5. doi: 10.3168/jds.S0022-0302(87)80301-6

62. Griffiths DW, Smith WHM. Variation in $S$-methyl cysteine sulphoxide concentration with harvest date in forage rape (Brassica napus). J Sci Food Agric. (1989) 47:249-52. doi: 10.1002/jsfa.2740470212

63. Jayanegara A, Togtokhbayar N, Makkar HPS, Becker K. Tannins determined by various methods as predictors of methane production reduction potential of plants by an in vitro rumen fermentation system. Anim Feed Sci Technol. (2009) 150:230-7. doi: 10.1016/j.anifeedsci.2008.10.011

64. Dillard SL, Roca-Fernández AI, Rubano MD, Elkin KR, Soder KJ. Enteric methane production and ruminal fermentation of forage brassica diets fed in continuous culture. J Anim Sci. (2018) 96:1362-74. doi: 10.1093/jas/ sky030

65. Durmic Z, Moate PJ, Jacobs JL, Vadhanabhuti J, Vercoe PE. In vitro fermentability and methane production of some alternative forages in Australia. Anim Prod Sci. (2016) 56:641-5. doi: 10.1071/AN15486

66. Wang $M$, Janssen $\mathrm{PH}$, Sun XZ, Muetzel S, Tavendale M, Tan $\mathrm{ZL}$, et al. A mathematical model to describe in vitro kinetics of $\mathrm{H}_{2}$ gas accumulation. Anim Feed Sci Technol. (2013) 184:1-16. doi: 10.1016/j.anifeedsci.2013.05.002

67. Tyagi AK, Singhal KK. Effect of mustard oil and glucosinolate on rumen fermentation. Indian J Anim Nutr. (1999) 16:12-8.

68. Lila ZA, Mohammed N, Kanda S, Kamada T, itabashi H. Effect of $\alpha$ cyclodextrin-allyl isothiocyanate on ruminal microbial methane production in vitro. Anim Sci J. (2003) 74:321-6. doi: 10.1046/j.1344-3941.2003.00123.x

69. Soliva CR, Amelchanka SL, Duval SM, Kreuzer M. Ruminal methane inhibition potential of various pure compounds in comparison with garlic oil as determined with a rumen simulation technique (Rusitec). Br J Nutr. (2011) 106:114-22. doi: 10.1017/S00071145100 05684
70. Lee KY, Kim KH, Baek YC, Ok JU, Seol YJ, Han KJ, et al. Effects of mustard seeds and powder on in vitro ruminal fermentation characteristics and methane production. J Anim Sci Technol. (2013) 55:25-32. doi: 10.5187/JAST.2013.55.1.25

71. Durge SM, Tripathi MK, Dutta N. In vitro fermentation characteristics and methane reduction potential of mustard cake (Brassica juncea L.). Vet World. (2016) 9:1141-6. doi: 10.14202/vetworld.2016.1141-1146

72. Pearce PE, Hunt CW, Hall MH, Loesche JA. Effects of harvest time and grass hay addition on composition and digestion of high- and low-glucosinolate rapeseed forage. J Prod Agric. (1991) 4:411-6. doi: 10.2134/jpa1991.0411

73. Todini L. Thyroid hormones in small ruminants: effects of endogenous, environmental and nutritional factors. Animal. (2007) 1:997-1008. doi: 10.1017/S1751731107000262

74. Liu YY, Milanesi A, Brent GA. Thyroid Hormones. In: Litwack G, editors. Hormonal Signaling in Biology and Medicine: Comprehensive Modern Endocrinology. London, UK: Academic Press (2020). p. 487-506. doi: 10.1016/B978-0-12-813814-4.00021-3

75. Barry TN, Duncan SJ. Iodine metabolism and thyroid hormone relationships in growing sheep fed on kale (Brassica oleracea) and ryegrass (Lolium perenne)-clover (Trifolium repens) fresh-forage diets. Br J Nutr. (1983) 49:241-53. doi: 10.1079/BJN19830031

76. Cox-Ganser JM, Jung GA, Pushkin RT, Reid RL. Evaluation of Brassicas in grazing systems for sheep: II. Blood composition and nutrient status. J Anim Sci. (1994) 72:1832-41. doi: 10.2527/1994.7271832x

77. Trávníček J, Kroupová V, Kursa J, Illek J, Thér R. Effects of rapeseed meal and nitrates on thyroid functions in sheep. Czech J Anim Sci. (2001) 46:1-10.

78. Okulicz M, Bialik I, Chichłowska J. The influence of sinigrin on thyroid hormones level and lipid metabolism in rat. Med Vet. (2002) 1:113-9. Available online at: http://www.acta.media.pl/pl/full/5/ 2002/000050200200001000010011300119.pdf

79. Ravichandiran S, Sharma K, Dutta N, Pattanaik AK, Chauhan JS, Agnihotri A. Comparative assessment of soybean meal with high and low glucosinolate rapeseed-mustard cake as protein supplement on performance of growing crossbred calves. J Sci Food Agric. (2008) 88:832-8. doi: 10.1002/jsfa.3159

80. Lee JW, Wang S, Huang Y, Seefeldt T, Donkor A, Logue BA, et al. Toxicity of canola-derived glucosinolates in pigs fed resistant starch-based diets. J Anim Sci. (2020) 98:skaa111. doi: 10.1093/jas/skaa111

81. Lopez-Rodriguez MF, Cymbaluk N, Epp T, Laarveld B, Serrano Recalde EC, Simko E, et al. Effects of the glucosinolate sinigrin in combination with a noniodine supplemented diet on serum iodine and thyroid hormone concentrations in nonpregnant mares. J Equine Vet Sci. (2020) 91:103110. doi: 10.1016/j.jevs.2020.103110

82. Mikulski D, Jankowski J, Zdunczyk Z, Juskiewicz J, Slominski BA. The effect of different dietary levels of rapeseed meal on growth performance, carcass traits, and meat quality in turkeys. Poult Sci. (2012) 91:215-23. doi: 10.3382/ps.2011-01587

83. Zhu LP, Wang JP, Ding XM, Bai SP, Zeng QF, Su ZW, et al. Effects of dietary rapeseed meal on laying performance, egg quality, apparent metabolic energy, and nutrient digestibility in laying hens. Livest Sci. (2018) 214:265-71. doi: 10.1016/j.livsci.2018.06.007

84. von Danwitz A, Schulz C. Effects of dietary rapeseed glucosinolates, sinapic acid and phytic acid on feed intake, growth performance and fish health in turbot (Psetta maxima L.). Aquaculture. (2020) 516:734624. doi: 10.1016/j.aquaculture.2019.734624

85. Kursa J, Trávníček J, Rambeck WA, Kroupová V, Vítovec J. Goitrogenic effects of extracted rapeseed meal and nitrates in sheep and their progeny. Vet Med. (2000) 45:129-40.

86. Stoewsand GS. Bioactive organosulfur phytochemicals in Brassica oleracea vegetables-A review. Food Chem Toxicol. (1995) 33:537-43. doi: 10.1016/0278-6915(95)00017-V

87. Felker P, Bunch R, Leung AM. Concentrations of thiocyanate and goitrin in human plasma, their precursor concentrations in brassica vegetables, and associated potential risk for hypothyroidism. Nutr Rev. (2016) 74:248-58. doi: 10.1093/nutrit/nuv110

88. Nishie K, Daxenbichler ME. Toxicology of glucosinolates, related compounds (nitriles, R-goitrin, isothiocyanates) and vitamin $U$ found in cruciferae. Food Cosmet Toxicol. (1980) 18:159-72. doi: 10.1016/0015-6264(80)90070-X 
89. Kennedy PM, Young BA, Christopherson RJ. Studies on the relationship between thyroid function, cold acclimation and retention time of digesta in sheep. J Anim Sci. (1977) 45:1084-90. doi: 10.2527/jas1977.4551084x

90. Lourenço AL, Cone JW, Fontes P, Dias-da-Silva AA. Effects of ambient temperature and soybean meal supplementation on intake and digestion of two sheep breeds differing in mature ize. J Anim Physiol Anim Nutr. (2010) 94:571-83. doi: 10.1111/j.1439-0396.2009.00942.x

91. Barnett MC, Goopy JP, Mcfarlane JR, Godwin IR, Nolan JV, Hegarty RS. Triiodothyronine influences digesta kinetics and methane yield in sheep. Anim Prod Sci. (2012) 52:572-7. doi: 10.1071/AN11303

92. Kyriacou A, McLaughlin J, Syed AA. Thyroid disorders and gastrointestinal and liver dysfunction: a state of the art review. Eur J Intern Med. (2015) 26:563-71. doi: 10.1016/j.ejim.2015.07.017

93. Pinares-Patino CS, Ulyatt MJ, Lassey KR, Barry TN, Holmes CW. Rumen function and digestion parameters associated with differences between sheep in methane emissions when fed chaffed lucerne hay. J Agric Sci. (2003) 140:205-14. doi: 10.1017/S0021859603003046

94. Goopy JP, Donaldson A, Hegarty R, Vercoe PE, Haynes F, Barnett M, et al. Low-methane yield sheep have smaller rumens and shorter rumen retention time. Br J Nutr. (2014) 111:578-85. doi: 10.1017/S0007114513002936

95. Bond JJ, Cameron M, Donaldson AJ, Austin KL, Harden S, Robinson DL, et al. Aspects of digestive function in sheep related to phenotypic variation in methane emissions. Anim Prod Sci. (2019) 59:55-65. doi: 10.1071/AN17141

96. Huhtanen P, Ramin M, Cabezas-Garcia EH. Effects of ruminal digesta retention time on methane emissions: a modelling approach. Anim Prod Sci. (2016) 56:501-6. doi: 10.1071/AN15507

97. Bain WE, Bezuidenhout L, Jopson NB, Pinares-Patino CS, McEwan JC. Rumen differences between sheep identified as being low or high emitters of greenhouse gas. Proc Assoc Advmt Anim Breed Genet. (2014) 20:376.
98. Kittelmann S, Pinares-Patiño CS, Seedorf H, Kirk MR, Ganesh S, McEwan JC, et al. Two different bacterial community types are linked with the low-methane emission trait in sheep. PLoS ONE. (2014) 9:e103171. doi: 10.1371/journal.pone.0103171

99. Shi W, Moon CD, Leahy SC, Kang D, Froula J, Kittelmann S, et al. Methane yield phenotypes linked to differential gene expression in the sheep rumen microbiome. Genome Res. (2014) 24:1517-25. doi: 10.1101/gr.1682 45.113

100. Xiang R, McNally J, Bond J, Tucker D, Cameron M, Donaldson AJ, et al. Across-experiment transcriptomics of sheep rumen identifies expression of lipid/oxo-acid metabolism and muscle cell junction genes associated with variation in methane-related phenotypes. Front Genet. (2018) 9:330. doi: 10.3389/fgene.2018.00330

101. Barnett MC, Mcfarlane JR, Hegarty RS. Low ambient temperature elevates plasma triiodothyronine concentrations while reducing digesta mean retention time and methane yield in sheep. J Anim Physiol Anim Nutr. (2015) 99:483-91. doi: 10.1111/jpn. 12252

Conflict of Interest: The author declares that the research was conducted in the absence of any commercial or financial relationships that could be construed as a potential conflict of interest.

Copyright (c) 2020 Sun. This is an open-access article distributed under the terms of the Creative Commons Attribution License (CC BY). The use, distribution or reproduction in other forums is permitted, provided the original author(s) and the copyright owner(s) are credited and that the original publication in this journal is cited, in accordance with accepted academic practice. No use, distribution or reproduction is permitted which does not comply with these terms. 